\title{
Metaplastic Breast Carcinomas and Their Relationship with Basal-Like Phenotype
}

\author{
Metaplastik Meme Karsinomları ve Bazal Benzeri Fenotip ile İlişkisi
}

\author{
Aslı ÇAKIR, İpek Işık GÖNÜL, Ömer ULUOĞLU
}

Department of Pathology, Gazi University, Faculty of Medicine, ANKARA, TURKEY

\begin{abstract}
Objective: Metaplastic carcinoma is a rare tumor showing high histological grade and low hormone receptor expression. It has pure epithelial and mixed types. Studies have suggested that metaplastic carcinomas may have a basal-like profile. Our aim was to evaluate the clinicopathological features of 11 metaplastic carcinomas and determine their resemblance to basal-like breast carcinomas regarding their morphological and immunohistochemical profile.
\end{abstract}

Material and Method: Eleven metaplastic carcinoma cases were reviewed for their histopathological features. All tumors but one were evaluated for the immunohistochemical expressions of the cytokeratin 5/6, cytokeratin 14 and epidermal growth factor receptor; and hormonal status was assessed.

Results: Four of eleven cases were carcinoma with chondroid metaplasia, 3 were adenosquamous carcinoma, 2 were squamous cell carcinoma and 2 were carcinosarcoma. The mean patient age was 53 years and the mean tumor size was $5,1 \mathrm{~cm}$. Histological grade was 3 for all with a nuclear grade of 3 . Average mitotic count was $31 / 10$ high power fields. Four cases had a central scar, 5 had central necrosis and 7 had geographic necrosis. Tumor growth pattern was pushing in 6 cases and no carcinoma in-situ was identified in 5 cases. Seven of 10 patients had axillary lymph node metastasis. Seven of 10 cases were triple-negative (estrogen receptor-, progesterone receptor-, HER2-) and 6 of them were positive for cytokeratin 5/6 and/or epidermal growth factor receptor, consistent with basal-like immunophenotype. Cytokeratin 14 was positive in 7 cases.

Conclusion: Metaplastic carcinomas are large-sized, high-grade tumors with prominent nuclear pleomorphism and frequent mitosis. They rarely overexpress hormone receptors and HER2 and generally have basal-like immunophenotype.

Key Words: Breast, Carcinoma, Metaplasia

\section{ÖZ}

Amaç: Metaplastik karsinom memenin nadir görülen yüksek dereceli tümörüdür. Epitelyal ve mikst (epitelyal+mezenkimal) tiplerden oluşur. Hormon reseptör ekspresyonu düşüktür. Çalışmalar, metaplastik karsinomların genetik olarak bazal-benzeri profile sahip olabileceğini belirtmektedir. Bu çalışmanın amacı, 11 metaplastik karsinom olgusunun klinikopatolojik özelliklerini araştırmak ve bazal-benzeri meme karsinomları ile benzerliklerini, morfolojik ve immünhistokimyasal profillerine bakarak, değerlendirmektir.

Gereç ve Yöntem: On bir metaplastik karsinom olgusunun, $1 s ̧ 1 k$ mikroskopik morfolojik özellikleri değerlendirildi. Primer tümöre ait kesitlerde, immünhistokimyasal olarak sitokeratin 5/6, sitokeratin 14 ve epidermal büyüme faktör reseptör ekspresyonları ile hormonal durumları incelendi.

Bulgular: Olguların dördü kondroid metaplazi gösteren karsinom, üçü adenoskuamöz karsinom, ikisi skuamöz hücreli karsinom ve ikisi karsinosarkom idi. Ortalama hasta yaşı 53, ortalama tümör çapı $5,1 \mathrm{~cm}$ idi. Tüm olgularda, tümörün nükleer derecesi ve histolojik derecesi 3 idi. 10 büyük büyütme alanındaki ortalama mitoz sayısı 31 olarak saptand. Dört olguda santral skar, beş olguda santral nekroz ve yedi olguda coğrafik nekroz izlendi. Altı olguda tümör iter tarzda büyüme gösteriyordu. Beş olguda karsinoma in situ saptanmadı. Lenf bezleri değerlendirilen 10 hastanın 7'sinde aksiller metastatik lenf bezi bulundu. İmmünhistokimyasal boyama yapılabilen 10 olgunun 7'si üçlü negatifti (östrojen reseptörü-, progesteron reseptörü-, HER2-) ve 6'sinda bazal-benzeri immünfenotip ile uyumlu olarak sitokeratin $5 / 6$ ve/veya epidermal büyüme faktör reseptörü pozitif idi. Sitokeratin 14, yedi olguda pozitif saptandı.

Sonuç: Metaplastik karsinomlar, büyük çaplı, belirgin nükleer pleomorfizm ve sık mitoz içeren yüksek dereceli tümörlerdir. Hormon reseptörleri ile HER2 ekspresyonları nadir görülür ve genellikle bazal-benzeri immünfenotip gösterirler.

Anahtar Sözcükler: Meme, Karsinom, Metaplazi
(Turk Patoloji Derg 2012, 28:134-141)

Received : 04.09.2011 Accepted : 06.12.2011
Correspondence: Aslı ÇAKIR

Department of Pathology, Gazi University, Faculty of Medicine, ANKARA, TURKEY

E-mail: erdoganasli@gmail.com Phone: +90 3122025488 


\section{INTRODUCTION}

Metaplastic carcinoma (MC) is a relatively rare tumor of the breast, with an incidence of less than 1\% (1). It encompasses a great histopathologic variation, which results from the malignant epithelium undergoing metaplasia to squamous cells or various mesenchymal elements (2). The World Health Organization (WHO) classifies MC as pure epithelial or mixed (epithelial and mesenchymal) type (1). According to the WHO, the epithelial type is sub-classified into squamous cell carcinoma (SCC), adenocarcinoma with spindle cell differentiation, and adenosquamous cell carcinoma (ASCC), while the mixed type is sub-classified into carcinoma with chondroid metaplasia ( $\mathrm{CwCM}$ ), carcinoma with osseous metaplasia and carcinosarcoma (1). Carcinomas showing chondroid or osseous metaplasia can also be named as "matrix producing carcinoma" by others, in which invasive carcinoma shows direct cartilaginous and/or osseous stromal matrix differentiation without a spindle cell component or osteoclastic giant cells (3).

Metaplastic carcinomas are generally known to present with larger tumor size and higher tumor grade $(4,5)$. They are usually negative for hormone receptors $(4,6)$. The incidence of axillary lymph node involvement is low but they show a greater risk of developing distant organ metastasis (4). Patients with MC generally have poorer outcomes than with high-grade invasive ductal carcinoma and they rarely benefit from conventional chemotherapy or hormonal therapy $(4,7,8)$.

The key concept in the pathogenesis and development of MCs is epithelial-mesenchymal transition (EMT). Lien et al. reported that the EMT-related genes were differentially upregulated in MC (9). Osaka et al. proposed two progression pathways of transition from the ductal component of the adenocarcinoma to the sarcomatous component; either transition directly from ductal to sarcomatous tissue or via squamous tissue (8).

Breast carcinomas were recently classified into 4 types as luminal, basal-like, normal breast-like and HER2 positive according to their gene expression profile by using global gene expression profiling (10). Since basal-like and HER2 positive groups were reported to have aggressive clinical behavior and poor prognosis (11), it was thought that an extra effort should be spent to diagnose these groups in a surgical pathology routine. Therefore, an immunohistochemical panel, proposed by Carey et al., including estrogen receptor (ER), progesterone receptor (PR), human epidermal growth factor receptor-2 (HER2), epidermal growth factor receptor (EGFR) and cytokeratin 5/6 (CK 5/6), was widely accepted for use in identifying breast carcinomas with basal-like immunophenotype as defined by cDNA microarrays (12). In the meantime, MCs have been shown to be a part of the spectrum of basal-like breast carcinomas, since they usually display a basal/myoepithelial and epithelial to mesenchymal molecular make-up $(13,14)$, basal-like immunophenotype, and triple negativity and often show expression of EGFR, CK14 and CK5/6 $(15,16)$.

The aim of our study was to evaluate the light microscopic histopathological features of 11 MCs that were diagnosed in our institution between the years of 2006 and 2009 and to investigate their relationship to basal-like immunophenotype.

\section{MATERIAL and METHODS}

\section{Case selection:}

A total of 468 breast carcinoma diagnoses were made at the Pathology Department of our institution between the years of 2006 and 2009. While all these cases were histopathologically being re-evaluated for a graduation thesis, $11 \mathrm{MCs}$ were determined and included in this study. The patient's age and gender, tumor size, surgical procedure type, the presence or absence of tumor invasion in the nipple, skin and fascia of the breast tissue, ER, PR, HER2 status of the tumor were all noted from the original pathology reports.

\section{Morphological parameters:}

All hematoxylin eosin (HE)-stained tumor slides were re-examined for the following morphological features to determine the histological subtype according to the WHO classification (1).

1. Grading was performed using the modified BloomRichardson method, in which tubule formation of the tumor cells, nuclear pleomorphism/atypia and mitotic count were assessed (17). Mitotic count was performed on an Olympus $\mathrm{BH} 2$ light microscope, with a graticule at 40x magnification and in 10 high-power fields (HPFs). Mitotic number was scored as 1 when it was between $0-7,2$ when between $8-14$ and 3 when 15 or more.

2. Tumor growth pattern was assessed as "infiltrative" if there was an irregular infiltration into the surrounding parenchyma/fat or "pushing" if the tumor was well circumscribed.

3. The necrosis with its type was noted as "present" or "absent". Large irregular areas of tumor necrosis was called "geographic necrosis" and necrosis in the middle of the tumor, mostly because of the metabolic imbalance between the cells and the vascular supply, was called "central necrosis". 
4. The presence or absence of carcinoma in situ (CIS) was determined.

5. The presence of a central scar defined as a central acellular area of tumor was looked for.

All HE-stained axillary lymph node slides were reviewed for a metastatic component.

\section{Immunohistochemistry}

The formalin-fixed, routinely processed and paraffinembedded tumor tissue blocks were available for 10 out of the 11 cases. One case was a consultation, for which only HE slides were present. Immunohistochemistry was performed in tissue micro array (TMA) blocks constructed for each case. The individual cases were represented with four different $0,1 \mathrm{~cm}$ cores in the blocks. The TMA blocks were stained with CK 5/6 (DAKO, Denmark, clone D5/16 B4, 1:100), CK 14(Spring bioscience, CA, USA, SPM 263, 1:100), and EGFR (DAKO, Denmark, clone E30, 1:100), using the standard immunohistochemical techniques. Diaminobenzidine was used as the chromogen and sections were counterstained using Harris hematoxylin. For each antibody, the percentage and the intensity of staining were evaluated and recorded. Tumors showing no staining were considered as negative. Nuclear staining observed in more than $1 \%$ of the tumor cells was regarded as positive for ER and PR. HER2 over expression was evaluated semi quantitatively and scores from 0 to 3 were given according to the staining intensity and the percentage of positive tumor cells for immunohistochemistry. The tumors with an immunohistochemical score of 3 and/or with HER2/ CEP ratio equal to or more than 2.2 in fluorescent in situ hybridization analysis were regarded as positive for HER2 gene amplification (18).

We defined basal-like immunophenotype as triple negative (TN) tumor with CK 5/6 and/or EGFR positivity according to the criteria of Carey et al. (12).

\section{RESULTS}

In this study, we included 11 cases of MCs for which eight mastectomy and 2 lumpectomy specimens were present. One case was a consultation for which we did not have either paraffin blocks or the pathology report. All the patients were female with an average age of 53 (range from 34 to 86$)$ years. Grossly, the tumor diameter ranged from 1.4 to $28 \mathrm{~cm}$ in size with a mean of $5.1 \mathrm{~cm}$. Microscopically, 6 cases were mixed type ( 4 were $\mathrm{CwCM}$ and 2 were

Table I: Clinicopathological and morphologic features of $11 \mathrm{MC}$ cases

\begin{tabular}{|c|c|c|c|c|c|c|c|c|c|c|c|c|c|}
\hline & $\begin{array}{l}\text { Histological } \\
\text { type }\end{array}$ & Age & $\begin{array}{l}\text { Tumor } \\
\text { size } \\
(\mathrm{cm})\end{array}$ & $\begin{array}{l}\text { Nuclear } \\
\text { score }\end{array}$ & $\begin{array}{l}\text { Tubule } \\
\text { score }\end{array}$ & $\begin{array}{c}\text { Mitotic } \\
\text { count }\end{array}$ & $\begin{array}{c}\text { Central } \\
\text { scar }\end{array}$ & $\begin{array}{l}\text { Central } \\
\text { necrosis }\end{array}$ & $\begin{array}{c}\text { Geographic } \\
\text { necrosis }\end{array}$ & CIS & $\begin{array}{l}\text { Growth } \\
\text { pattern }\end{array}$ & $\begin{array}{c}\text { Metastatic } \\
\text { component } \\
\text { in lymph } \\
\text { node }\end{array}$ & $\begin{array}{l}\text { Basal-like } \\
\text { immuno- } \\
\text { phenotype }\end{array}$ \\
\hline Case 3 & CwCM & 44 & 3.5 & 3 & 3 & 32 & + & + & + & - & Pushing & Epithelial & + \\
\hline Case 4 & CwCM & 52 & 4.2 & 3 & 3 & 28 & - & + & + & + & Pushing & Epithelial & + \\
\hline Case 5 & ASCC & 54 & 1.4 & 3 & 3 & 22 & - & - & - & + & Infiltrative & $\begin{array}{c}\text { No } \\
\text { metastasis }\end{array}$ & + \\
\hline Case 6 & ASCC & 35 & 3.5 & 3 & 2 & 37 & + & + & + & - & Infiltrative & $\begin{array}{l}\text { Glandular } \\
\text { and } \\
\text { squamous }\end{array}$ & - \\
\hline Case 8 & \begin{tabular}{|c|} 
Carcinosar- \\
coma
\end{tabular} & 55 & 1.8 & 3 & 3 & 15 & - & - & - & - & Infiltrative & Epithelial & + \\
\hline Case 9 & $\begin{array}{c}\text { Carcinosar- } \\
\text { coma }\end{array}$ & 34 & 28 & 3 & 3 & 63 & - & - & + & + & Infiltrative & $\begin{array}{c}\text { No } \\
\text { metastasis }\end{array}$ & + \\
\hline Case 10 & SCC & 65 & 3.5 & 3 & 3 & 24 & - & - & + & - & Infiltrative & Epithelial & - \\
\hline Case 11 & SCC & 47 & 3.6 & 3 & 3 & 22 & - & + & - & + & Pushing & N/A & N/A \\
\hline
\end{tabular}

(N/A: not available) 
carcinosarcoma) and 5 cases were pure epithelial type (3 were ASCC, 2 were SCC).

\section{Morphological findings (Table I, Figure 1A-H)}

All of the tumors were grade 3 with a nuclear score and mitotic score of 3 . The mean mitotic count was $31 / 10 \mathrm{HPFs}$, ranging from 15 to 63 . The score for tubule formation was 2 only in 2 cases (18.2\%), and a score of 3 was given for the remaining 9 cases.

Four $(36 \%)$ of the 11 cases had a central scar, 5 (45\%) had central necrosis, and 7 (64\%) had geographic necrosis. Carcinoma in situ did not accompany 5 cases (45\%). All of the CwCM cases, 1 case of ASCC and 1 case of SCC had pushing margins while the remaining 5 cases $(45 \%)$ had infiltrative margins.

Ten patients had an axillary lymph node biopsy and 7 (70\%) of them had 1 to 26 metastatic lymph nodes. The metastatic component was only epithelial in 6 cases (Figure 2A). A case of CwCM (case 1) had an epithelial dominant metastatic deposit with chondroid matrix production in the lymph node (Figure 2B). One of the carcinosarcomas (case 9) had both skin and fascia invasion and 1 ASCC (case 6) had fascia invasion.
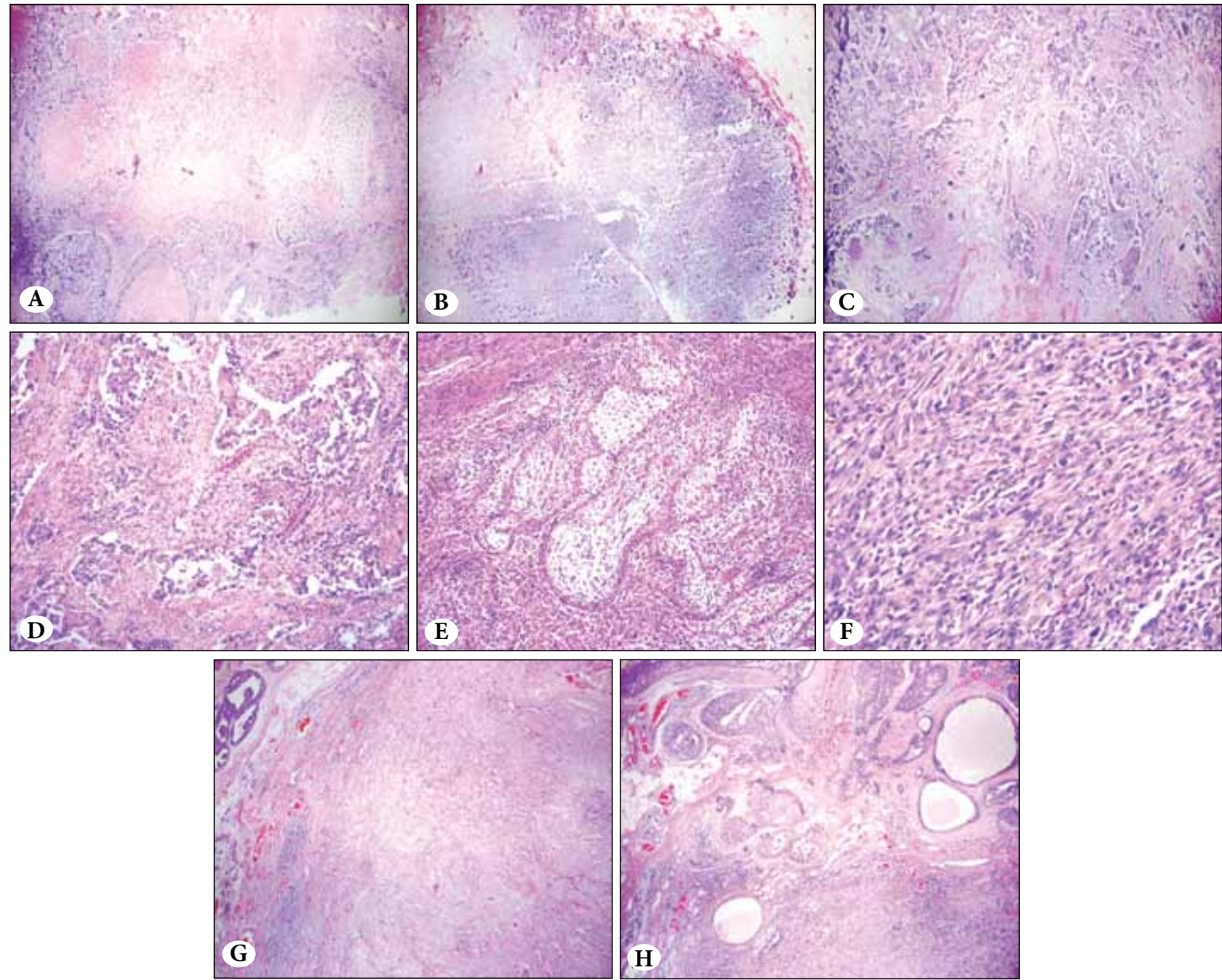

Figure 1: (A) Carcinoma with chondroid metaplasia. Chondroid island adjacent to the tumor cells with prominent nucleoli in solid tumor (H\&E, x200). (B) Carcinoma with chondroid metaplasia. Tumor has pushing margins and large necrosis on the left (H\&E, $\mathrm{x} 200$ ) (C) Geographic necrosis in the adenocarcinoma component (H\&E, x400). (D) Adenosquamous carcinoma. Pleomorphic adenocarcinomatous tumor cells intermingle with squamous cells with keratin pearls (H\&E, x200) (E) Carcinosarcoma. Pleomorphic epitheloid and spindle tumor cells (H\&E, x100). (F) Carcinosarcoma. Spindle tumor cells have plenty mitosis and atypia (H\&E, x400) (G) Pure SCC with pushing margins (H\&E, x40). (H) Pure SCC. Nests of pleomorphic, apoptotic tumor cells (H\&E, x400). 


\section{Immunohistochemical findings (Table II, Figure 3A-C)}

Immunohistochemical staining was performed in 10 cases. Cytokeratin 5/6 was positive in all cases except case 1 (90\%). Cytokeratin 14 was expressed in all 4 cases of the $\mathrm{CwCM}$, in one ASCC, in one carcinosarcoma and in one SCC (70\%). Epidermal growth factor receptor was positive in half of cases (3 CwCM, 1 ASCC and 1 SCC). Estrogen receptor and HER2 were negative in 9 cases $(90 \%)$. PR was negative in $8(80 \%)$ cases.

Seven cases (70\%) had TN hormonal status. Out of these, 6 were positive for cytokeratin $5 / 6$ and/or EGFR and these were found to be consistent with basal-like immunophenotype.

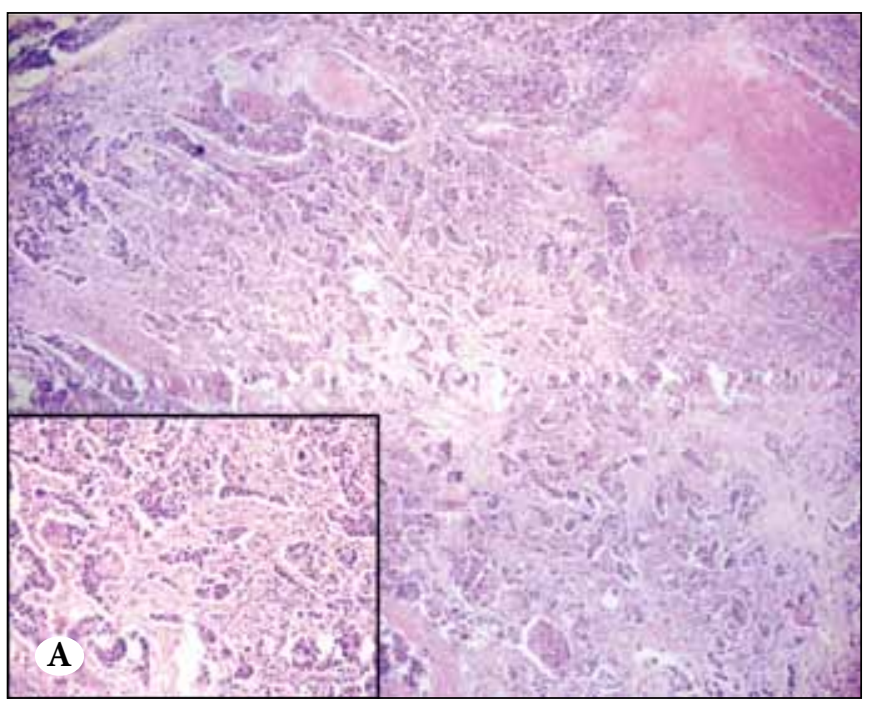

\section{DISCUSSION}

Metaplastic carcinoma is a heterogeneous group of neoplasms, characterized by squamous, spindle cell, and/or mesenchymal metaplasia/differentiation composed of numerous distinct histological entities with or without a conventional adenocarcinomatous component. Since MCs are rare, comprising less than $1 \%$ of invasive breast neoplasms, the reported data are relatively limited. We analyzed 11 cases of MC, including $4 \mathrm{CwCM}, 3$ ASCC, 2 carcinosarcoma and 2 SCC cases by morphological and immunohistochemical evaluations in this study to better understand this rare but heterogeneous tumor category.

All patients in this study were female and the mean patient

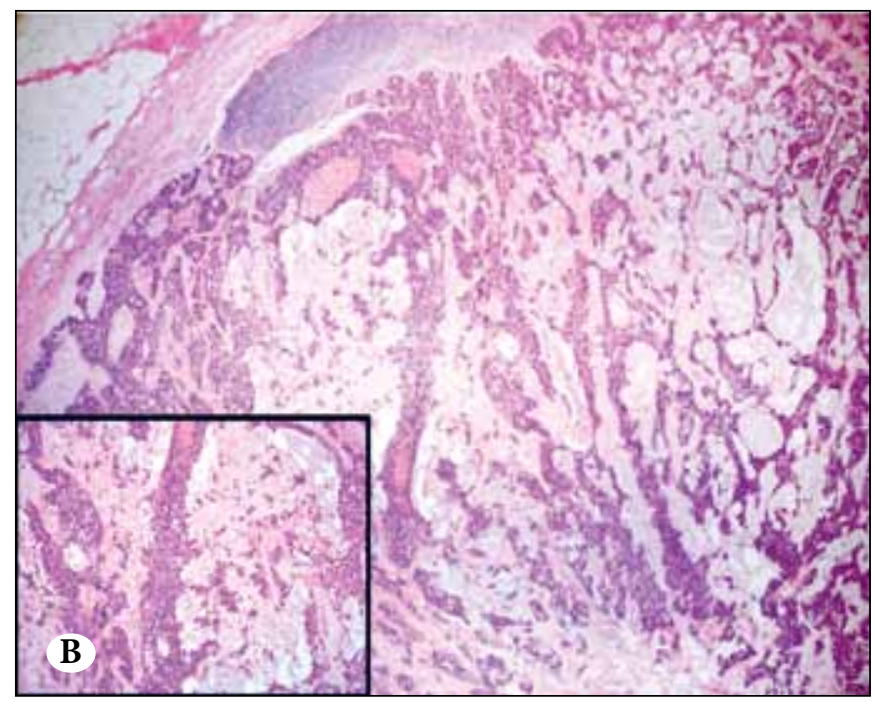

Figure 2: Axillary lymph node metastasis. (A) Adenosquamous carcinoma (case 7). Both squamous and adenocarcinomatous components can be seen (H\&E, x100. Inset: H\&E, x200). (B) Carcinoma with chondroid metaplasia (case 1). Both adenocarcinoma and chondroid matrix can be seen (H\&E, $x 40$. Inset: $H \& E, x 100)$.

Table II: Immunohistochemical features of MCs

\begin{tabular}{|l|l|c|c|c|c|c|c|c|}
\hline & Histological type & ER & PR & HER2 & CK5/6 & CK14 & EGFR & $\begin{array}{c}\text { Basal-like } \\
\text { immunophenotype }\end{array}$ \\
\hline Case 1 & CwCM & - & - & - & - & $90 \%,+++$ & - & - \\
\hline Case 2 & CwCM & - & - & - & $100 \%,+++$ & $90 \%,+++$ & $10 \%,++$ & + \\
\hline Case 3 & CwCM & - & - & - & $100 \%,+++$ & $5 \%,+++$ & $5 \%,++$ & + \\
\hline Case 4 & CwCM & - & - & - & $100 \%,+++$ & $5 \%,+++$ & $40 \%,++$ & + \\
\hline Case 5 & ASCC & - & - & - & $70 \%,+++$ & - & - & + \\
\hline Case 6 & ASCC & - & $10 \%$ & - & $100 \%,+++$ & $60 \%,+++$ & $5 \%,++$ & - \\
\hline Case 7 & ASCC & $20 \%$ & $20 \%$ & - & $40 \%,++$ & - & - & - \\
\hline Case 8 & Carcinosarcoma & - & - & - & $100 \%,+++$ & - & - & + \\
\hline Case 9 & Carcinosarcoma & - & - & - & $5 \%,+++$ & $5 \%,+++$ & - & + \\
\hline Case 10 & SCC & - & - & + & $100 \%,+++$ & $60 \%,+++$ & $20 \%,+++$ & - \\
\hline Case 11 & SCC & N/A & N/A & N/A & N/A & N/A & N/A & N/A \\
\hline
\end{tabular}

(N/A: not available). 




Figure 3: (A) Positive cytoplasmic staining for CK 5/6 (x100), (B) Positive cytoplasmic staining for CK 14 (x100), (C) Positive membranous staining for EGFR (x100). age was 53 years. Grossly, the tumor size ranged from 1.4 to $28 \mathrm{~cm}$ with a mean value of 5,1 and a median of $3,5 \mathrm{~cm}$, similar to other studies that have demonstrated that most MCs were larger than $2 \mathrm{~cm}(4-6,19)$. One study found that tumor size was best correlated with prognosis (2), whereas this was not true in another study (20).

All of the tumors we analyzed in the study were grade 3 and the nuclear score was also 3 with the presence of pleomorphic and atypical nuclei. The lesions were frequently solid and only 2 of them had a tubule score of 2 . The tumors were rich in mitotic figures with an average mitotic count of $31 / 10$ HPFs. The histopathological features observed in our series are similar to the description in the previous studies $(4,5$, $7,15,16,21,22)$. In addition, 3 cases had a central scar, 5 had central necrosis, 7 had geographic necrosis and 6 had a pushing growth pattern. In two studies, $43 \%$ and $64 \%$ of the tumors respectively were purely invasive MCs with no insitu component $(21,23)$. Similarly, we did not observe CIS in 5 cases (45\%) in our series. High histological grade, large tumor size, the presence of frequent geographic necrosis and low CIS rates may indicate that MCs grow rapidly.

The expression of hormone receptors and HER2 have been reported to be low in MC's (5-7). Estrogen receptor positivity was ranging from 0 to $19.2 \%$, PR positivity was 0 to $35.7 \%$, HER2 expression was 0 to $15.7 \%$ and TN was 80.4 to $100 \%(14,15,21-27)$. Jung et al. also indicated that frequency of a TN status was higher in MCs than invasive ductal carcinomas (28). Similarly, we found only 1 case to be positive for ER, only 2 cases to be PR- positive and HER2 over expression to be present in only one SCC. Seventy percent of MCs, including all of the CwCM and carcinosarcoma cases, were TN.

Metaplastic carcinomas are thought to develop through a phenotypic transformation of epithelial cells into basal/ myoepithelial cells which then transform into carcinoma and sarcoma (25). Cytokeratin 5/6 and CK14 are basal keratins and their expressions suggest a phenotype of EMT. Wang et al. showed that CK5/6 and CK14 had a significant association with a diagnosis of $\mathrm{MC}$ and that CK5/6 was more sensitive than CK14 (25). In our study, 9 cases (90\%) were positive for $\mathrm{CK} 5 / 6$ and 7 cases (70\%) were positive for CK14. Only 1 CwCM lacked CK5/6 expression but this case expressed CK14. Therefore, all of our cases showed positivity for basal keratins, either CK5/6 or CK14.

Epidermal growth factor receptor, which is a member of the ErbB family of transmembrane tyrosine kinase receptors, is a sensitive marker (100\%) for identifying MCs, but has a low specificity (19,2\%) (22). Metaplastic carcinomas feature over expression and amplification of EGFR protein, at rates 
of $57-83,3 \%$ and $26-34 \%$, respectively $(16,25,27,29)$. It has been also shown that EGFR immunohistochemical expression correlates with EGFR amplification (30). We found that $50 \%$ of our cases ( $3 \mathrm{CwCM}$ cases, 1 ASCC case and 1 SCC case) showed immunohistochemical expression of EGFR; and 2 carcinosarcoma cases (100\%) lacked EGFR expression. Although MCs have reported to have high levels of expression and amplification of EGFR, they were shown to lack EGFR activating mutations $(16,29)$. Therefore it is not clear whether EGFR tyrosine kinase inhibitors are effective for the treatment of MCs. For the next step of the study, we are planning to extend the series and add molecular methods to look for the amplification of the gene for EGFR.

Recent studies demonstrated that regardless of the type of metaplastic elements, MCs showed basal-like phenotype, ranging from $91 \%$ to $100 \%$, which was confirmed by both expression array analysis and immunohistochemistry (13, $14,25,31)$. In this study, 6 cases $(60 \%)$ showed basal-like immunophenotype, which included all carcinosarcomas and 3 out of $4 \mathrm{CwCM}$ cases.

Basal-like breast carcinomas have been observed to possess specific histopathological features such as high-grade nuclei, high mitotic rate, lack of well-formed ductal structures, presence of central and geographic necrosis, central scar and pushing tumor borders $(32,33)$. When we look for the presence of these morphological features of basal-like phenotype in MCs showing basal-like immunophenotype, the high nuclear pleomorphism (100\%), high mitotic rate $(100 \%)$ and lack or scantiness of ductal structures (100\%) were the most consistent features. Accordingly, all basal-like MCs were histological grade 3. Other common features were geographic necrosis (66.7\%), which was most frequently seen in $\mathrm{CwCM}$ cases, and pushing tumor borders (50\%). Most of the MCs with geographic necrosis had basal-like immunophenotype (57\%). On the other hand, central necrosis (33.3\%) and central scar (16.7\%) were less common. There was no CIS component associated with invasive carcinoma in half of the basal-like MCs.

Axillary lymph node involvement in MCs has been documented to be low in previous reports, with an incidence of $15-36.3 \%(4,5,20,22,31)$. However, two groups reported that more than half of their patients had axillary lymph node metastases $(15,26)$. In addition, in their series of $12 \mathrm{MC}$ cases, Wang et al. found that all their tumors had axillary lymph node involvement (25). In our study of 10 patients, 7 (70\%) were found to have axillary lymph node metastasis. The histological subtypes of the primary tumor in the lymph node positive patients were $\mathrm{CwCM}$ in 3 cases, ASCC in 2 cases, carcinosarcoma in 1 case and SCC in 1 case. The nodal metastases demonstrated malign glandular and/or squamous elements except in a case of $\mathrm{CwCM}$ (case1), which showed chondroid matrix production within adenocarcinoma. This finding may also support the idea that EMT occur in both primary tumor and nodal metastases of MCs (8) .

Patients with MC are thought to exhibit a poorer outcome than patients with invasive ductal carcinoma, invasive lobular carcinoma and $\mathrm{TN}$ invasive ductal carcinoma $(5,6,19,28)$. There is no consensus on the prognosis of MC subtypes worldwide. Oberman et al. and Okada et al. observed that no significant difference was present in clinical outcome among their patients with different MC subtypes $(2,6)$. On the other hand, Yamaguchi et al. indicated that high grade spindle cells in MCs may be important with respect to poor prognosis (34). Generally, prognosis of MCs is determined by tumor stage at the time of diagnosis.

In conclusion, MCs tend to have large tumor size, high histological grade, prominent nuclear pleomorphism and plenty of mitotic figures morphologically. All cases in this study expressed either one of the basal keratins. The majority of the cases were found to have TN hormonal status and more than half of the cases had a basal-like immunophenotype. Besides having high scores for the each parameter of the conventional grading schema (nuclear pleomorphism, tubule formation and mitosis), the presence of geographic necrosis is another morphological feature of basal-like breast carcinoma that was also commonly detected in MCs.

\section{REFERENCES}

1. Tavassoli F, Devilee P: World Health Organization Classification of Tumours. Pathology and Genetics. Tumours of the Breast and Female Genital Organs. Lyon, France, IARC Press, 2003, 37-41

2. Oberman HA: Metaplastic carcinoma of the breast. A clinicopathologic study of 29 patients. Am J Surg Pathol 1987, 12: 918-929

3. Wargotz ES, Norris HJ: Metaplastic carcinomas of the breast. I. Matrix-producing carcinoma. Hum Pathol 1989, 20: 628-635

4. Pezzi CM, Patel-Parekh L, Cole K, Franko J, Klimberg VS, Bland $K$ : Characteristics and treatment of metaplastic breast cancer: analysis of 892 cases from the National Cancer Data Base. Ann Surg Oncol 2007, 14: 166-173

5. Luini A, Aguilar M, Gatti G, Fasani R, Botteri E, Brito JA, Maisonneuve P, Vento AR, Viale G: Metaplastic carcinoma of the breast, an unusual disease with worse prognosis: the experience of the European Institute of Oncology and review of the literature. Breast Cancer Res Treat 2007, 101: 349-353

6. Okada N, Hasebe T, Iwasaki M, Tamura N, Akashi-Tanaka S, Hojo T, Shibata T, Sasajima Y, Kanai Y, Kinoshita T: Metaplastic carcinoma of the breast. Hum Pathol 2010, 41: 960-970 
7. Beatty JD, Atwood M, Tickman R, Reiner M: Metaplastic breast cancer: clinical significance. Am J Surg 2006, 191: 657-664

8. Osako T, Horii R, Ogiya A, Iijima K, Iwase T, Akiyama F: Histogenesis of metaplastic breast carcinoma and axillary nodal metastases. Pathol Int 2009, 59: 116-120

9. Lien HC, Hsiao YH, Lin YS, Yao YT, Juan HF, Kuo WH, Hung MC, Chang KJ, Hsieh FJ: Molecular signatures of metaplastic carcinoma of the breast by large-scale transcriptional profiling: identification of genes potentially related to epithelialmesenchymal transition. Oncogene 2007, 26: 7859-7871

10. Kauppila JH, Takala H, Selander KS, Lehenkari PP, Saarnio J, Karttunen TJ: Increased Toll-like receptor 9 expression indicates adverse prognosis in oesophageal adenocarcinoma. Histopathology 2011, 59: 643-649

11. Nielsen TO, Hsu FD, Jensen K, Cheang M, Karaca G, Hu Z, Hernandez-Boussard T, Livasy C, Cowan D, Dressler L, Akslen LA, Ragaz J, Gown AM, Gilks CB, van de Rijn M, Perou CM: Immunohistochemical and clinical characterization of the basallike subtype of invasive breast carcinoma. Clin Cancer Res 2004, 10: 5367-5374

12. Carey LA, Perou CM, Livasy CA, Dressler LG, Cowan D, Conway K, Karaca G, Troester MA, Tse CK, Edmiston S, Deming SL, Geradts J, Cheang MC, Nielsen TO, Moorman PG, Earp HS, Millikan RC: Race, breast cancer subtypes, and survival in the Carolina Breast Cancer Study. JAMA 2006, 295: 2492-2502

13. Weigelt B, Kreike B, Reis-Filho JS: Metaplastic breast carcinomas are basal-like breast cancers: a genomic profiling analysis. Breast Cancer Res Treat 2009, 117: 273-280

14. Reis-Filho JS, Milanezi F, Steele D, Savage K, Simpson PT, Nesland JM, Pereira EM, Lakhani SR, Schmitt FC: Metaplastic breast carcinomas are basal-like tumours. Histopathology 2006 49: $10-21$

15. Tse GM, Tan PH, Putti TC, Lui PC, Chaiwun B, Law BK: Metaplastic carcinoma of the breast: a clinicopathological review. J Clin Pathol 2006, 59: 1079-1083

16. Gilbert JA, Goetz MP, Reynolds CA, Ingle JN, Giordano KF, Suman VJ, Blair HE, Jenkins RB, Lingle WL, Reinholz MM, Adjei AA, Ames MM: Molecular analysis of metaplastic breast carcinoma: high EGFR copy number via aneusomy. Mol Cancer Ther 2008, 7: 944-951

17. Elston CW, Ellis IO: Pathological prognostic factors in breast cancer. I. The value of histological grade in breast cancer: experience from a large study with long-term follow-up. Histopathology 1991, 19: 403-410

18. Wolff AC, Hammond ME, Schwartz JN, Hagerty KL, Allred DC, Cote RJ, Dowsett M, Fitzgibbons PL, Hanna WM, Langer A, McShane LM, Paik S, Pegram MD, Perez EA, Press MF, Rhodes A, Sturgeon C, Taube SE, Tubbs R, Vance GH, van de Vijver M, Wheeler TM, Hayes DF: American Society of Clinical Oncology/ College of American Pathologists guideline recommendations for human epidermal growth factor receptor 2 testing in breast cancer. J Clin Oncol 2007, 25: 118-145

19. Bae SY, Lee SK, Koo MY, Hur SM, Choi MY, Cho DH, Kim S, Choe JH, Lee JE, Kim JH, Kim JS, Nam SJ, Yang JH: The prognoses of metaplastic breast cancer patients compared to those of triple-negative breast cancer patients. Breast Cancer Res Treat 2011, 126: 471-478

20. Dave G, Cosmatos H, Do T, Lodin K, Varshney D: Metaplastic carcinoma of the breast: a retrospective review. Int J Radiat Oncol Biol Phys 2006, 64: 771-775
21. Barnes PJ, Boutilier R, Chiasson D, Rayson D: Metaplastic breast carcinoma: clinical-pathologic characteristics and HER2/ neu expression. Breast Cancer Res Treat 2005, 91: 173-178

22. Nassar A, Sookhan N, Santisteban M, Bryant SC, Boughey JC, Giorgadze T, Degnim A: Diagnostic utility of snail in metaplastic breast carcinoma. Diagn Pathol 2010, 5: 76

23. Lien HC, Lin CW, Mao TL, Kuo SH, Hsiao CH, Huang CS: p53 overexpression and mutation in metaplastic carcinoma of the breast: genetic evidence for a monoclonal origin of both the carcinomatous and the heterogeneous sarcomatous components. J Pathol 2004, 204: 131-139

24. Lim KH, Oh DY, Chie EK, Han W, Im SA, Kim TY, Park IA, Noh DY, Ha SW, Bang YJ: Metaplastic breast carcinoma: clinicopathologic features and prognostic value of triple negativity. Jpn J Clin Oncol 2010, 40: 112-118

25. Wang H, Guan B, Shi Q, Ma H, Zhou H, Wang X, Zhou X: May metaplastic breast carcinomas be actually basal-like carcinoma? Further evidence study with its ultrastructure and survival analysis. Med Oncol 2011, 28: 42-50

26. Al Sayed AD, El Weshi AN, Tulbah AM, Rahal MM, Ezzat $A A$ : Metaplastic carcinoma of the breast clinical presentation, treatment results and prognostic factors. Acta Oncol 2006, 45: 188-195

27. Leibl S, Moinfar F: Metaplastic breast carcinomas are negative for Her-2 but frequently express EGFR (Her-1): potential relevance to adjuvant treatment with EGFR tyrosine kinase inhibitors? J Clin Pathol 2005, 58: 700-704

28. Jung SY, Kim HY, Nam BH, Min SY, Lee SJ, Park C, Kwon Y, Kim EA, Ko KL, Shin KH, Lee KS, Park IH, Lee S, Kim SW, Kang HS, Ro J: Worse prognosis of metaplastic breast cancer patients than other patients with triple-negative breast cancer. Breast Cancer Res Treat 2010, 120: 627-637

29. Reis-Filho JS, Pinheiro C, Lambros MB, Milanezi F, Carvalho S, Savage K, Simpson PT, Jones C, Swift S, Mackay A, Reis RM, Hornick JL, Pereira EM, Baltazar F, Fletcher CD, Ashworth A, Lakhani SR, Schmitt FC: EGFR amplification and lack of activating mutations in metaplastic breast carcinomas. J Pathol 2006, 209: 445-453

30. Shao MM, Zhang F, Meng G, Wang XX, Xu H, Yu XW, Chen LY, Tse GM: Epidermal growth factor receptor gene amplification and protein overexpression in basal-like carcinoma of the breast. Histopathology 2011, 59: 264-273

31. Znati K, Chahbouni S, Hammas N, Bennis S, Abbas F, Harmouch T, Chbani L, Elfatemi H, Amarti A: Twelve cases of metaplastic carcinoma of the breast: experience of the university hospital of Fez Morocco. Arch Gynecol Obstet 2011, 283: 845-849

32. Fulford LG, Easton DF, Reis-Filho JS, Sofronis A, Gillett CE, Lakhani SR, Hanby A: Specific morphological features predictive for the basal phenotype in grade 3 invasive ductal carcinoma of breast. Histopathology 2006, 49: 22-34

33. Livasy CA, Karaca G, Nanda R, Tretiakova MS, Olopade OI, Moore DT, Perou CM: Phenotypic evaluation of the basal-like subtype of invasive breast carcinoma. Mod Pathol 2006, 19: 264-271

34. Yamaguchi R, Horii R, Maeda I, Suga S, Makita M, Iwase T, Oguchi M, Ito Y, Akiyama F: Clinicopathologic study of 53 metaplastic breast carcinomas: their elements and prognostic implications. Hum Pathol 2010, 41: 679-685 